SCHOLARS: Journal of Arts \& Humanities

[Peer-Reviewed, Open Access, Indexed in NepJOL]

Print ISSN: 2773-7829; e-ISSN: 2773-7837

Volume 1, August 2019, pp. 1-9

Central Department of English

DOI: https://doi.org/10.3126/sjah.v1i0.34443

Tribhuvan University

Kirtipur, Kathmandu, Nepal

www.cdetu.edu.np/eiournal/

\title{
University Autonomy and Academic Freedom: A Commitment to Truth
}

\author{
Amma Raj Joshi, PhD \\ Central Department of English \\ Tribhuvan University, Kirtipur, Nepal
}

\begin{abstract}
This paper analyzes several aspects of university autonomy, explores the conditions of Nepali universities and suggests what Nepal needs to do to ensure autonomous academic environment at the universities for creation and expansion of knowledge. Based on the reflections of thinkers, educationists and the personal experience of the writer as a faculty at Tribhuvan University of Nepal, I conclude that Nepali universities are under the political and bureaucratic gaze; they are far from becoming the enclaves of free thinkers and knowledge seekers. As a result, academic freedom is doubtful until universities gain autonomous decision-making powers in structural, academic, financial and administrative fronts.
\end{abstract}

Keywords: University, academic autonomy, academic freedom

“. . .the modern university should be without condition. The university professes the truth and that is its profession. It declares and promises an unlimited commitment to truth." - Jacques Derrida

\section{Introduction}

In this paper, I have explained the concepts of "university autonomy and academic freedom" at a time when universities are under a restrictive gaze of government, politicians, bureaucrats, media, society and common public in general and have attempted to reveal the attributing factors of autonomy, to relate the Nepali situation and finally to make certain suggestions for ensuring such autonomy and freedom. Let me clear at the outset: I neither specialize in this body of knowledge, nor 
University Autonomy and Academic Freedom 2

hold any position of a policymaker or an educationist. I am simply an avid and curious learner who has passionately devoted four decades in and around the centers of learning, constantly questioning myself and the world across. I am interested in reflecting upon what autonomy means for a university; what academic freedom entails; and what these issues mean to academics and outsiders. I have supported my views with the ideas of renowned thinkers and have tried to unravel the contested yet deeply meaningful issues of university autonomy and academic freedom, without any claim that they are irrefutable and unquestionable. However, what follows are my cherished assumptions and beliefs on academic environment. I confess that I have dwelt upon Jacques Derrida's concept that "University should be without condition" and it should have "unlimited commitment to truth" (24). I have shaped my views on the issue of university autonomy based on his ideas and reflected upon the ground realities of our university autonomy and freedom.

A university, through teaching, research and innovation and its capacity to address the complex global problems, empowers human beings by bringing them to the domain of light-knowledge. It is a location where scholars create a new body of knowledge about fathomable and unfathomable, immediate and remote, concrete and abstract phenomena of the world and beyond; where they envision things differently in a broad light through their constant perusal of knowledge and skills. The learned scholars have the capacity to constantly question and churn out different and dissenting position, unlike the mass that does not largely disagree. The Bhagvad Gita highlights this capacity of the enlightened to see the world differently:

$$
\begin{aligned}
& \text { yānïsāSarba-bhutānām } \\
& \text { tasyāmJāgartisamyami } \\
& \text { yasyāmJāgartibhutānām } \\
& \text { SānisāPasyatoMuneh (69) } \\
& \text { oflgzf ;j\{ e"tfg+ft:of+ hfult\{; ;odL } \\
& \text { o:d+fhfu|tLe"tflg ;f lgzfkZotf] d'g]M }
\end{aligned}
$$

(The night for all beings is the time of awakening for the self-controlled and the time of awakening for other beings is night for the introspective sage)

I consider professors at the location of the university the learned sages/scholars who do have the capacity to see things differently and make out different meanings unlike those who peddle on the thoroughfares. And for those who attempt to elevate themselves to the sublime heights of knowledge, Noam Chomsky suggests, "inquire and create, search the riches of the past, develop quest for understanding and learn on their own without being subjected to indoctrination resulting from the activism of 1960” (Chomsky, 2012). 
University Autonomy and Academic Freedom 3

\section{University Autonomy}

University autonomy is a precondition for creating an environment to lead humanity to light and learning, for making human beings constantly question things they come across, for creating new body of knowledge and, ultimately, for comprehending the world better. If universities are not autonomous; if they do not have the rights to make independent decisions; if they have to adhere to the dictates of state power; if they face the threat of laws that aim at curtailing and limiting their structural, financial, administrative and academic functioning, academic freedom cannot be promoted and knowledge growth is stunted. Thus, autonomy is a precondition to academic freedom. If university autonomy is under gaze, academic freedom is strangulated. If university autonomy is restricted and academic freedom is denied, the innate worth of education to create better human beings, who think and express freely, truthfully, creatively and critically is impossible because dissenting voices are silenced and free views are infringed in such an environment.

University autonomy refers to how free universities are from the excessive intervention of the government, bureaucracy, political syndicates, media and society in general. The European University Association (EUA) has defined four dimensions of autonomy: organizational, financial, staffing and academic and specified the indicators to elaborate the issue of university autonomy. Following the similar line of thought Muhammad Murtaza points out the academic, organizational, financial and staffing (Murtaza) situation of Pakistani universities. Other literatures on university autonomy also reveal a common consensus that universities should have academic, structural, financial and administrative decision-making power without any outside intervention. All these indicators meaningfully indicate why universities need autonomy not only at the academic level but also in other decision-making processes. Let us elaborate these significant concerns.

University's autonomy depends on how independently the university manages its academic activities: academic calendars, students' admissions, development of courses/syllabuses, program choices, introduction of degrees, assurance of quality and standard, enhancement of academic collaboration, provisions of students' scholarship programs, selection of faculty for trainings and advanced scholarship, approval of grants and leaves and decisions onacademic programs for the benefit of the society in general.

Organizational autonomy determines whether or not the university has been functioning properly. Does the university have power to select executive leadership, policy-making bodies and legal bodies within the university? Can the university create academic structures and designate right people without intervention and political syndicating? Such pertinent issues remain crucial in making a university autonomous. 
University Autonomy and Academic Freedom 4

Funds generation, management and dispersion/expenditure authority are the linchpin of the university governing system. A university unable to manage its finances and generate financial resources is likely to suffer unimaginable loss while depending on outside sources. Unless the university is financially autonomous to make decisions, autonomy does not quite work.

Finally, university's performance primarily depends on its human resource management. The university should strengthen its capacity to select qualified faculty and administrative staff, carry out national and international academic collaborations without intervention, manage remunerations, execute recruitment and promotion procedures and encourage meritocracy and rational legitimacy.

\section{Nepali Experience}

Where are Nepali universities in terms of these fundamental issues? Do they have unrestricted license or do they face constant unwarranted interventions in university affairs? If they face interventions and infringements, what course do they need to take?

Nepali universities face a bizarre challenge in academic matters. Though the universities are principally called autonomous bodies by the legislation, unprecedented and unpredictable challenges are day-to-day phenomena. Universities do not have program inceptions and admissions under their control. No university has been able to strictly follow its academic calendar. Big events - mostly political - taking place in the country affect the calendar of the university. Academic activities, including admission procedures and exam schedules are directly affected by students' pressures and irrelevant interventions. Strict admissions criteria cannot be applied, even if desired. Even those segments trying to follow strict norms fall under great threats. Medical education can be taken for an example. Right from the approval of the program to admissions of the students, a big commotion takes place: which college to be given a chance to run medical degrees or other financially lubricative degrees in applied sciences is out of the discretion of the executive authority though it is under their authority principally. Many things decided by business syndicates, such as political parties, students' political wings, professors' political/ideological affiliations, bureaucrats at the ministry to name a few. University executives take formal decisions but do not have guts to own them. Even admissions to the programs are at times generally affected. A current example of such intervention in admissions was seen at the Faculty of Law of the Tribhuvan University in 2018 when it had to scrap the already conducted entrance and open the floodgates to admit every applicant beyond its managerial capacity.

Not only have academic calendars, admissions, college affiliations and authority delegation to run academic programs in certain subjects been distantly monitored and manipulated by extra-territorial power groups. Internal academic procedures like 
University Autonomy and Academic Freedom 5

terminal or unit tests and final examinations have been seriously jeopardized by pressure groups of students. The university academics/faculty cannot make independent decisions on fundamental issues: curricula, teaching strategies, medium of instruction, students' evaluation and the formulation of code of conduct for the classes. Faculty members have often been threatened to award students unfair grades. Non-academic parameters set and dictated by the government bodies for students' scholarship demean the dignity of the university and create confusion as to how to accommodate the mediocre with the meritorious and maintain quality of education. The public rhetoric and concern about educational-quality deterioration is the offshoot of such outside intercession. The university environment, extremely influenced by political syndicates, discourages academic excellence and promotes mediocrity.

Similarly, organizational malfunctioning has reduced academic institutions and universities to locations of shame. Nepali universities as locations of light and learning have now been facing a harsh situation of desperately covering their shame - may it be in setting the educational quality, academic integrity, evoking common people's respect to it, or projecting their images to the world outside.

The process of selecting the executives and academic authorities for academic structures has literally decimated the image of the university as a domain without condition. Be it a Program Coordinator or the Head of a Department, Campus Chief, Director, Dean, Service Commission authority or any other university official, everyone comes to power or gains a position depending on their efficiency to approach political syndicates and everyone appointed faces intervention of some type at every stage. All major positions - academic or administrative - within the university are now determined by political affiliation. In Tribhuvan University, the largest university of the country, all organizational decisions regarding appointments of academic and administrators within the internal structure are political. The main executives of the university function at the command of politicians who appointed them and the campus, departments, sections and branch chiefs/heads adhere to the command of executive/s with similar political affiliations. Such a scenario shadows the cherished ideals of academic immersion of the university. Imagining autonomy and talking about deterioration in academic quality without seceding universities from political influence is an act of deception. Is the country serious about education? Do the government, politicians and bureaucrats realize that the fall of educational quality at schools and universities of Nepal is because of their intervention? Why should anybody spend time in teaching/working when sycophancy can bring about magical rewards?

Such an organizational enslavement continues and together with it, financial dependence on the government has made a crippling effect on the university. There is now a constant debate between the UGC and the universities regarding the funds. It 
University Autonomy and Academic Freedom 6

appears as if these institutions are made for rivalry. (The Tribhuvan University authority has a crippling sense of the lack of funds because the UGC headcounts while allocating the budget; whereas the UGC complains that the TU does not reveal how many people (faculty and staff) are working in it). It appears as if the government has no responsibility toward nation's education and the budget allocated by the government is a mercy scheme to help those who work in the universities. Government financing to the university is limited to the salary of the staff. Investment on physical infrastructures, research and development facilities appear rare. Budget allocation to the university reveals a decreasing trend and universities have to follow government's norms in generating resources through tuition fees and other research engagements. Meagre resource funding and strict regulatory impositions indicate the paradoxical situation universities have to face.

Apart from academic, organizational and financial dynamics, the recruitment of faculty and staff, the selection of qualified people--right people in the right place, the issues of their management, promotion and facilities question the nature of university autonomy in Nepal. Many clandestine activities taking place in the faculty and staff hiring competitions invite disgrace to the universities. Many a times, politicians dictate universities to employ people in academic positions without assessing their credibility for such posts. Competitive examinations have been massively ridiculed. Why does such a thing happen? The response lies in the organizational composition. There are hurdles in academic exchange and academic collaboration where the need of academic freedom is seriously felt. One example of such infringement of academic freedom is the intervention in a VC's travel by the nation's Prime Minister only because he is the ceremonial chancellor and that his whims are final. Such a situation seriously decimates the image of the university and the state of university autonomy and academic freedom.

In Nepal, obstructions prevail on the way to university autonomy. But it does not mean that autonomy is the cure of all ills and that autonomy should come undeserved to the universities. The university personnel, including staff and faculty should have a high level of professional ethics and academic integrigy with equal sense of responsibility and accountability. As academics, they are now at a juncture to question where they stand; what they do; what they have accomplished academically; and what they should aim at in order to make the university domains without condition, a shrine of learning, a venue of constant creative and critical thinking, a place where values change not because the governments force things, but because people behave in a different and righteous way as a result of what they have learnt at the university. They have to change education, as Ken Robinson speculates, by making it economically adaptable and creative, culturally friendly to local and global identities, socially and personally invigorating. Though Noam Chomsky argues that thinking of education as whether it is worthwhile investment 
University Autonomy and Academic Freedom 7

is a distortion of education because true education for him aims to raise free, creative and independent individuals able to gain from the cultural achievement of the past the inherent worth of education (Chomsky, 2012). The university academics need to contemplate on their share in uplifting the image of the university through their personal ethics, professional and academic integrity, persistent learning and unflinching commitment to knowledge and truth. Otherwise, the sloganeering for university autonomy would be a move towards anarchism and institutional annihilation. The right demeanor of the academic, the structural, administrative and academic reformations of the university should allow it move forward as an autonomous body where individuals may profess academic freedom. Possibilities exist that devious sycophants will reap benefit of the efforts of ethically motivated and seriously engaged academicprofessionals. Wisdom, understanding and knowledge of the just academic will be instrumental in supplying beautiful treasures of autonomy and academic freedom which we look for. "Saying of the wise" is pertinent to recall at this point:

By wisdom a house is built and through understanding it is established through knowledge its rooms are filled with rare and beautiful treasures. (Bib: Psalms)

My emphasis is on the wisdom of the faculty and professors, who build the university through their understanding and knowledge and fill up this house with the treasure of knowledge and light. Much more depends on whether they reveal this wisdom or indulge in the mediocrity of political syndicates and fall victim to them and victimize the shrine of learning as well. In their decision to choose lies the notion of university autonomy and academic freedom.

The academic is an individual who makes informed, intelligent choices and decisions for the collective good through creative and critical thinking. John Dewey was inspired by the vision of liberal, free society and thought of the "need of freedom and equality, emancipation from social bounds to liberate individuals and society from the structures of power" (Sikandar 193) and thought that it could be done by applying experiential (193) process of education. Experiential education allows freedom of thought, judgment and power to execute decision freely in a democratic way. Democracy for Dewey is not only about voting rights; it is also about making citizens take responsibility and make right choices and decisions judiciously (166). Thus, academic freedom is a condition that democratically empowers people to express things by not only demanding rights, but taking responsibility, too.

Derrida's observations hold some weight at this juncture. He viewed that "The principle of unconditional resistance is a right that the university itself should ... reflect, invent and power" (26) as it could help the university and the academics to oppose "state 
University Autonomy and Academic Freedom 8

power, economic power, the power of media, ideological, religious and cultural power powers that limit democracy (26). Derrida's view rightly reflects upon why we need academic freedom. As academics, we have the rights to frankly and freely speak the truth irrespective of its consequences on governments, laws, regulations, media, any ideological, religious or cultural powers because that is what democracy professes and demands and that is for the greatest good.

\section{Conclusion}

Academic freedom is, thus, against any silencing factors that contravene free views. But academic freedom comes with a cost: it demands ethical standing, professional particularity, academic rigor and integrity, commitment to truthfulness, constant vigilance, unwavering determination to do only the right thing, strong creative and critical impulse, excellence in learning and strong democratic inclination. In the absence of these virtues and values academic freedom will simply be reduced to the means of meeting the selfish motives in the name of academics.

This discussion invites academics to reflect upon their activities. Do they really understand what academic freedom entails? Do they deserve and honor it? Or is it that they want to use a mask of academic freedom to hide their ugly and tarnished face? Let them be honest and let them profess the truth! If they do, the day will not be far when they will be able to make universities autonomous bodies where free thinkers organize, manage their organizations, profess truth fearlessly without falling victim to temptations.

\section{Works Cited}

Beteille andre. Universities at the Crossroads. OUP, 2010.

Chomsky, Noam. Noam Chomsky: The Purpose of Education (Learning without Frontiers). Jan. 25, 2012, www.learningwithout frontiers.com.

Derrida, Jacques. "The Future of Profession or the University without Condition (thanks to the 'Humanities,' what could take place tomorrow).” Jacques Derrida and the Humanities: A Critical Reader, edited by Tom Cohen, Cambridge UP, 2001, pp. 24-57.

Dewey, John. Democracy and Education. Echo Library, 1916. Murtaza, Muhammand. "University Autonomy". The Nation. May 16, 2017. www.nation.com.pk/16May-2017/university-autonomy.

Prabhupada, Swami, trans. Bhagavad Gita As It Is. $3^{\text {th }}$ ed. The Bhaktivedanta Book Trust, 1986.

Robinson, Ken. How to Change Education. Sept. 18, 2017. www.thersa.org/events/audio-an. 
University Autonomy and Academic Freedom 9

Sikandar, Aliya. "John Dewey and His Philosophy of Education." Journal of Education and Educational Development, vol. 2, no. 2, Dec. 2015, pp. 191-201.

Terdiman, Richard. "Determining and the Undetermined: Derrida's University without Condition." Eighteenth Century Studies, vol. 40, no. 3, Spring 2017, pp. 425441.

The European University Association. University Autonomy in Europe. n.d. www.university-autonomy.eu.ac. 